\title{
Equine Herpes Virus 1 (EHV-1) in Liver, Spleen, and Lung as Demonstrated by Immunohistology and Electron Microscopy
}

\author{
By Lars Jönsson, Johan Beck-Friı, Lena H. M. Renström, Tapıo Nikkilä, Per Thebo \\ and Bo Sundquist
}

Laboratory of Pathology and the Division of Vaccine Research, National Veterinary Institute, Uppsala, Sweden.

\begin{abstract}
Jönsson L., J. Beck-Friis, L. H. M. Renström, T. Nikkilä, P. Thebo and B. Sundquist: Equine Herpes Virus 1 (EHV-1) in liver, spleen, and lung as demonstrated by immunohistology and electron microscopy. Acta vet. scand. 1989, 30, 141-146. - Ten aborted foals, diagnosed as infected with Equine Herpes Virus 1 (EHV-1) on histopathological criteria, were examıned for the presence of EHV-1 using immunohistology as the investigative instrument. The primary reagent was an antiserum specific for viral envelope glycoproteins. Immunohistology localised EHV-1 to areas of liver necrosis and to the cytoplasm of infected Kupffer cells and hepatocytes. Cytoplasmic immunolabelling was also prominent in reticular cells of the red pulp of the spleen and in intact and degenerated bronchiolar epithelium. Cytoplasmic immunolabelling was seen in morphologically unchanged cells and in cells containing intranuclear inclusion bodies. Three aborted foetuses with no histological signs of EHV-1 infection were negative when immunostained for EHV-1.

Detection by electron microscopy of EHV-1 virions confirmed the EHV-1 specificity of the immunolabelling procedure.
\end{abstract}

equine virus abortion; immunolabelling; tissue sections.

\section{Introduction}

Equine Herpes Virus 1 (EHV-1) is the causative agent of equine virus abortion (Bürki et al. 1965, Chowdhury 1986) and the pathology of the disease has been described by several authors (Westerfield \& Dimock 1946, Jeleff 1957, Prickett 1970, Campbell \& Studdert 1983, Allen \& Bryans 1986).

As a complement to conventional histopathology, immunohistology can be a valuable tool for the diagnosis of EHV-1 infections. Gimeno et al. (1987) reported the immunohistological detection of EHV-1 in routinely prepared liver tissue sections of aborted foetuses. In this report we describe the demonstration of EHV-1 in infected specimens of liver, spleen, and lung by immunohistology and electron microscopy.

\section{Materials and methods \\ Histological specimens}

The material consisted of deparaffinised tissue sections of formalin-fixed, paraffin-embedded specimens of liver, spleen, and lung from 10 aborted horse foetuses, all diagnosed to be infected with EHV-1 by means of histopathological criteria. Three aborted foetuses with no signs of EHV-1 infection served as negative controls. 


\section{Virus}

Subtype 1 RAC-h strain of EHV-1 was propagated in pig kidney cells (PK-15) grown as roller bottle monolayer cultures in growth medium consisting of Eagle's MEM supplemented with $5 \%$ newborn calf serum. Cell culture medium was harvested $48 \mathrm{~h}$ post infection and clarified by filtration through Whatman GF/D glassfiber filters. Virus was purified from cell culture medium and the procedures used were ultrafiltration (Filtron, $100 \mathrm{~K}$ ) and gel chromatography over a column of Sepharose 6 Fast Flow (Pharmacia Fine Chemical, Uppsala, Sweden). The virus peak was solubilized by adding $1 \%$ Triton $\mathrm{X}-100$ before envelope glycoproteins were purified by lectin affinity chromatography (manuscript in preparation).

\section{Iscom antigen}

Virus glycoproteins were incorporated into immunostimulating complexes (iscoms) (Morein et al. 1984). Iscoms were prepared as previously described (Howard et al. 1987). Quil-A to a final concentration of $0.05 \%$ was added to the purified glycoproteins dissolved in the dialyzabel detergent $\mathrm{N}$-decanoyl-N-methylglucamine (Mega-10) before extensively dialyzed against 0.05 $\mathrm{mol} / \mathrm{l}$ Tris, $0.1 \mathrm{~mol} / \mathrm{l} \mathrm{NaCl}, \mathrm{pH} 7.4$. The amount of protein in the iscom antigen preparation was measured according to the method of Bradford (1976).

\section{Antiserum}

A rabbit was inoculated intramuscularly with 2 doses of the iscom antigen containing $50 \mu \mathrm{g}$ protein per dose at 1 month intervals. Three months after the last inoculation the rabbit was given a second booster dose of the iscoms and 2 weeks later blood was collected for serum preparation which was used throughout this investigation.

\section{Immunoblot}

Enzyme-linked immunoelectrotransfer blot (EITB) was performed to detect antibodies to glycoproteins of EHV-1. A whole virus preparation of EHV-1 was analyzed in $10 \%$ sodium dodecylsulphate (SDS) polyacrylamide gel electrophoresis (PAGE) according to the method of Laemmli (1970) and the virus antigens were transferred to nitrocellulose membranes according to Kyhse-Andersen (1984). The strips were preincubated in phosphate-buffered saline (PBS) $(\mathrm{pH}$ 7.2) containing $0.5 \%$ bovine serum albumine (BSA) and $0.1 \%$ Tween 20 for $0.5 \mathrm{~h}$ at room temperature. Rabbit serum and Con-A (10 $\mathrm{mg} / \mathrm{ml}$ ) were both diluted $(1: 100)$ in the same buffer and incubated over night at room temperature and washed in 3 changes of PBS. The strips were incubated with either a Protein-A (Sigma, St. Louis, MO) or a rabbit anti-Con-A (Dakopatts, Denmark) peroxidase conjugate diluted $1: 1000$ in preincubation buffer for $2 \mathrm{~h}$ at room temperature and washed in 3 changes of PBS. The peroxidase conjugate was localized by incubating the strips in the substrate 3-amino9-ethyl-carbazole (Sigma, St. Louis, MO) (pH 5.9) containing $0.05 \% \mathrm{H}_{2} \mathrm{O}_{2}$.

Analysis by EITB demonstrated that the rabbit serum reacted with 5 viral antigens. These coincided in molecular weights with 5 viral glycoproteins (Fig. 1) that according to Allen \& Bryans (1986) originate in the viral envelope.

\section{Immunohistology}

Endogenous peroxidase activity was blocked by incubating sections for $20 \mathrm{~min}$ in 0.05 mol/l TRIS-HCL pH 7.6 buffer (which was used in all rinsing steps throughout the immunostaining procedure) with $0.3 \% \mathrm{H}_{2} \mathrm{O}_{2}$. After a thorough rinse in buffer, sections were incubated with $2 \%$ BSA in buffer for $10 \mathrm{~min}$. Sections were gently drained and in- 


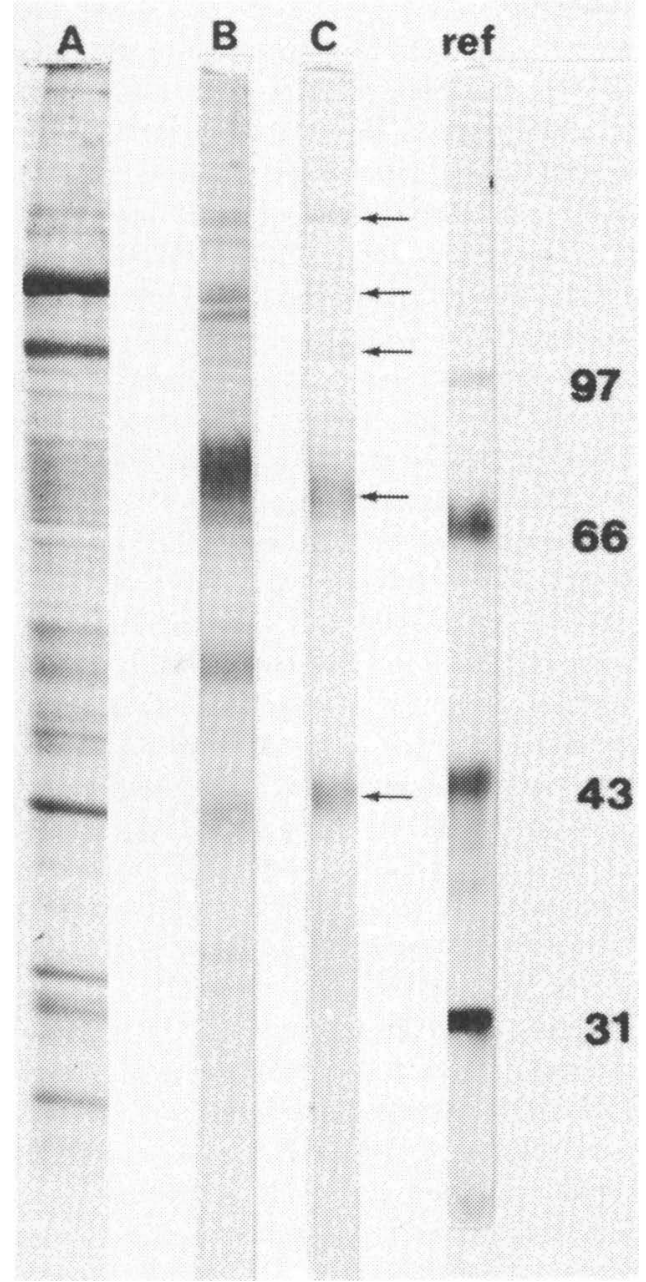

Figure 1. Analysis of the EHV-1 virion protein pattern by SDS-PAGE in a $10 \%$ SDS-gel (lane A). Visualization of the EHV-1 glucoproteins by specific binding of the lectin Con-A to glycoprotens (lane B). Identification of EHV-1 glycoproteins by immunoblot analysis of rabbit antibodies to EHV-1 iscoms (lane C). The reference lane shows the molecular weight marker proteins $(\times 1000)$.

The arrows show the EHV-1 glucoproteins.

cubated with antibodies to EHV-1, diluted $1 / 50$ in buffer containing $1 \%$ BSA (which was used for all subsequent dilutions), for 30 min. After another rinse in buffer, sections were consecutively incubated with swine anti-rabbit IgG and rabbit PAP-complex (DAKOPATTS), diluted $1 / 20$ and $1 / 100$, respectively. Sections were rinsed in buffer between and after these steps which both lasted for $30 \mathrm{~min}$. Peroxidase activity was visualised by rinsing sections in $0.06 \%$ diamino-bensidine (DAB, SIGMA) and $0.034 \% \mathrm{H}_{2} \mathrm{O}_{2}$ in buffer for $8 \mathrm{~min}$. Sections were rinsed in tap water, counterstained with haematoxylin, and finally mounted in Eukitt. Controls included: preimmune rabbit serum instead of anti-EHV-1 serum, application of anti-EHV-1 serum on non-infected tissues and absorption of anti-EHV-1 antibodies with EHV-1 before tissue incubation.

\section{Electron microscopy}

Formalin-fixed specimens of liver, lung, and spleen were post-fixed in Karnofsky's fixative $(1.5 \%$ paraformaldehyde $+1.5 \%$ glutaraldehyde). Specimens were consecutively placed in $1 \%$ osmium tetroxide and $1 \%$ uranylacetate. They were then dehydrated and embedded in Epon. Thin sections were stained with uranylacetate and lead citrate.

\section{Results}

The pattern of immunostaining was consistent with the histopathological lesions typical for equine virus abortion. Prominent labelling of viral antigen was evident in areas of liver necrosis, and in the cytoplasm of hepatocytes and Kupffer cells (Fig. 2), in cells with intranuclear inclusion bodies and in those showing no overt changes. The cytoplasm of reticular cells of the red pulp of the spleen exhibited a marked staining whereas the necrotic lymphatic follicles were devoid of staining. Degenerated bron- 
chial epithelium was distinctly labelled. Intact epithelial cells and cellular debris in the bronchial lumen showed staining for viral antigen. Bronchial epithelial cells and reticular cells of the spleenic red pulp were frequently seen to contain intranuclear inclusion bodies. No labelling was identified in the control sections.

Electron microscopy revealed viral nucleocapsids in the condensed mass of chromatin in hepatocytic nuclei, i.e. the structure seen in the light microscope as an inclusion body (Fig. 3). Vacuoles in the cytoplasm of bronchiolar epithelial cells and the reticular cells of the spleenic red pulp contained complete virions (Figs. 4 and 5). In hepatocytes, fused intranuclear membranes and vacuoles were clearly visible and bundles of tonofilaments were seen woven around the nucleus (Fig. 3).

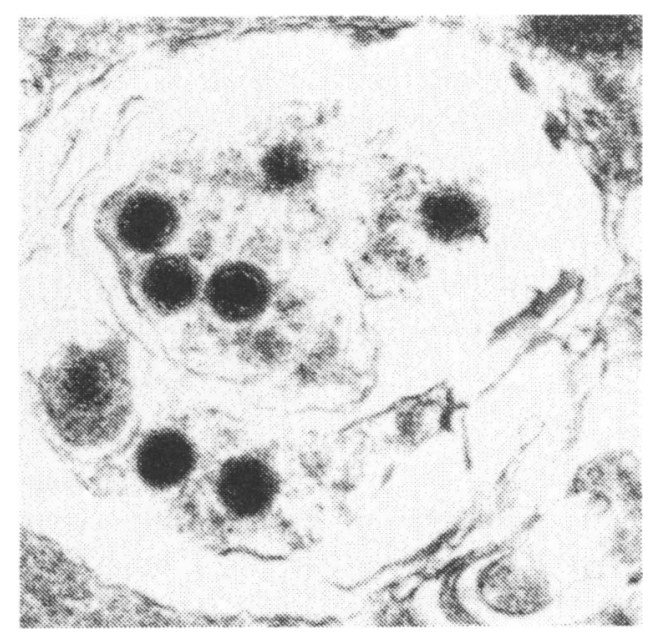

Figure 5. Reticular cell of the red pulp of the spleen containıng virions in a cytoplasmic vacuole. $\times 90000$.

\section{Discussion}

This study describes the immunohistological detection of EHV-1, and its verification by electron microscopy, in liver, spleen, and lung from aborted foetuses, using antibodies to viral envelope glycoproteins. No nuclear immunolabelling was evident as herpes virus nucleocapsids acquire an envelope by budding from the inner nuclear membrane (Darlington \& Moss 1968, O'Niell et al. 1984). The immunohistological findings are thus consistent with the electron microscopy studies in localizing virions to the cytoplasm of infected cells. Hepatocytic intranuclear inclusion bodies - the condensed chromatin containing compact aggregations of viral nucleocapsids - were corresponding to those described by Arhelger et al. (1963). Fused intranuclear membranes and vacuoles have been observed in concurrence with herpes virus envelopment (Nll et al. 1968, Darlington \& Moss 1968). It remains unclear, however, whether the presence of tonofilament bundles around the nucleus is a response to EHV-1 infection or not. Cytoplasmic virions were seen aggregated in vacuoles as has earlier been reported by Fong \& Hsiung (1972).

Microscopic lesions in the form of focal liver necrosis, degeneration of the spleenic white pulp and the bronchial and alveolar epithelium and intranuclear inclusion bodies in hepatocytes, reticular cells of the marginal zone of spleenic lymphatic follicles and bronchial epithelial cells are histologically diagnostic features typical for an EHV-1 infection. Together with a complement-binding test this has so far formed the basis for the diagnosis of equine virus abortion. However, immunohistological localisation of viral antigen in formalin-fixed, paraffinembedded specimens of infected tissues will improve the diagnostic capacity for EHV-1 infections. In our system we have used an antiserum containing antibodies specific for those viral envelope glycoproteins which are the major immunogenic components of 
Lars Jonsson, Johan Beck-Frıls, Lena H M Renstrom, Tapıo Nıkkıla, Per Thebo and Bo Sundquıst Equine herpes virus 1 (EHV-1) in liver, spleen, and lung as demonstrated by immunohistology and electron microscopy.

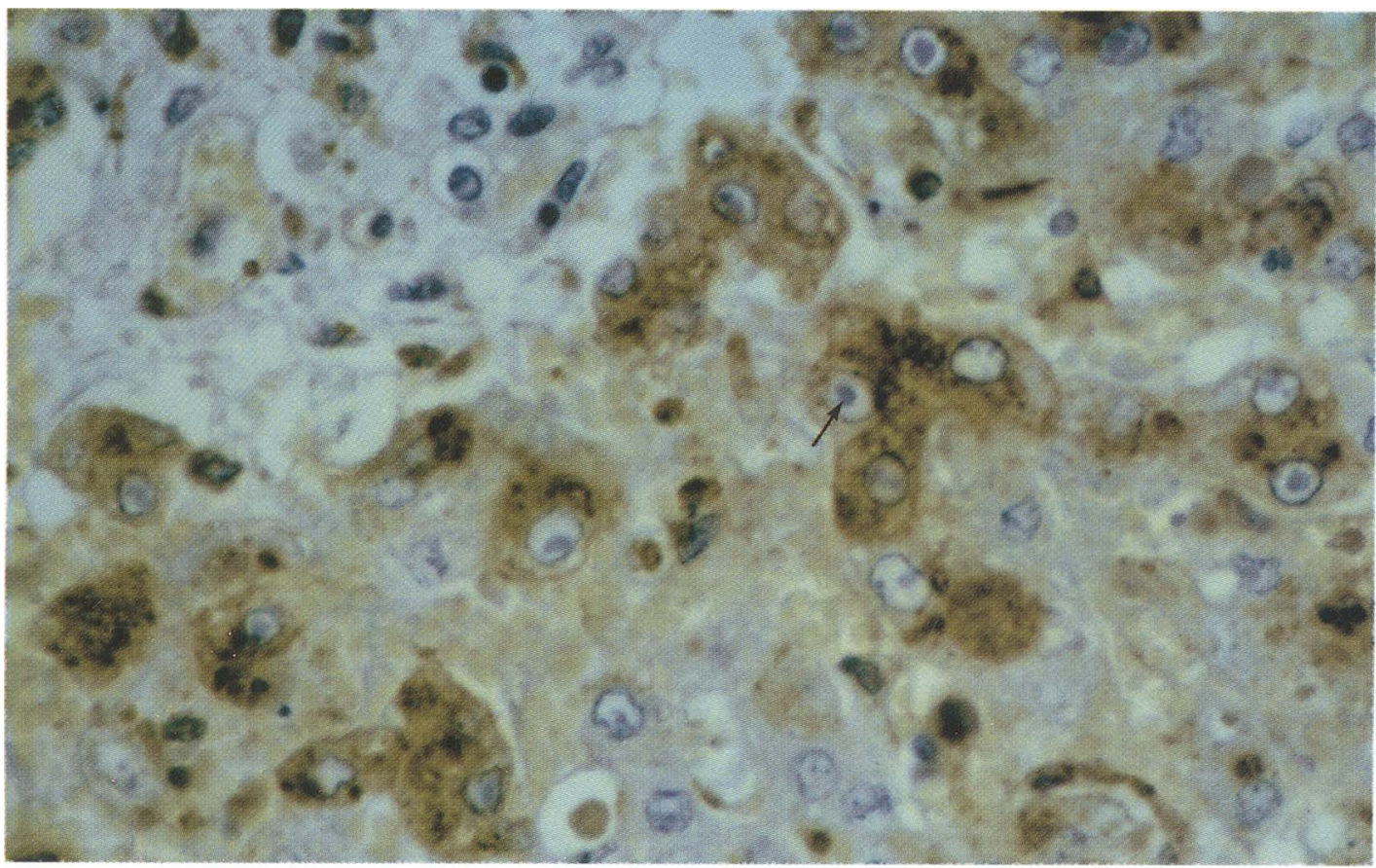

Figure 2. Immunostainıng for EHV-1 revealıng viral antigen focally distributed in the liver parenchyma. The cytoplasm of hepatic cells is distinctly labelled Arrow shows intranuclear inclusion body $\times 640$ 



Figure 3. Condensed chromatın contaınıng aggregations of viral nucleocapsids in an EHV-1 infected hepatocyte as evidenced by electron microscopy (observed in the light microscopy as an inclusion body). Arrows show A/ viral nucleocapsids $B$ / intranuclear membranes $\mathrm{C} /$ intranuclear vacuoles and D/ tonofilament bundles. $\times 19200$.

Figure 4. Virions in a cytoplasmic vacuole in a bronchiolar epithelial cell. $\times 150000$. 
EHV-1 (Turtinen 1983). Thus our immunological probe detects only complete virus particles present in the cytoplasm of infected cells. This narrow specificity of the primary antiserum potentially diminishes the risk of unspecific staining making the technique valuable as a routine diagnostic tool.

The common characteristic for the cases examined was a degenerated bronchial epithelium which exhibited a prominent immunolabelling for EHV-1. Lesions in liver and spleen were correlated with the pattern of immunostaining. Absence of lesions in these organs rendered no labelling of viral antigen. It thus seems as a prerequisite that histopathological lesions are present in inner organs, i.e. liver, lung, and spleen in order to obtain a proper immunohistological detection of EHV-1.

The immunohistological detection of EHV-1 presented in this report confirms the presence of viral antigen in tissues from aborted foetuses. As other viral agents are suspected to cause similar syndroms, e.g. equine parvovirus (Wong et al. 1985), it is of value that a reliable diagnosis can be made. The immunoperoxidase technique offers several advantages to the pathologist: it is easy to perform, retrospective studies are made possible, and preparations are permanent.

Due to the detection principle of a threestep antibody chain the method is very sensitive. Finally, labelling of antigen can be correlated with tissue pathology in the same section.

\section{Acknowledgements}

The authors wish to thank Miss Cajsa Magnusson, Mrs. Lena Ekman and Mr. Bengt Ekberg for technical assistance and Mrs. Ulla Malmström for preparing the manuscript. Prof. Claes Rehbinder and Ass. Prof. Berndt Klingeborn are gratefully acknowledged for critıcally evaluating the results.

\section{References}

Allen $G$, Bryans $J$ Molecular epızootology, pathogenesis and prophylaxis of equine herpesvirus-1 infections. Prog. Vet. Microbiol. Immun. 1986, 2, 78-144.

Arhelger $R$, Darlington $R$, Randall $C$ : An electron microscopic study of equine abortion virus infection in hamster liver. Amer. J. Pathol. 1963, 42, 703-707.

Bradford $M \cdot$ A rapid and sensitive method for the quantıfication of microgram quantities of protein utilizing the princıple of protein-dye binding. Analytical Biochemistry 1976, 72, 248-254.

Bürkı $F$, Bärlswyl $K$, Lindt $S$ Nachweis des Virus der Equiner Rhinopneumonitis als Ursache von Stutenaborten. (Demonstration of equine rhino pneumonitis virus as a cause of abortion in mares). Schw. Arch. Tierheilk. 1965, 107, 386-392.

Campbell T, Studdert $M$ : Equine herpesvirus type 1. Vet. Bull. 1983, 53, 135-146.

Chowdhury S, Kubin G, Ludwig $H^{\cdot}$ Equine herpesvirus type 1 (EHV-1) induced abortions and paralysis in a lipizzaner stud: a contribution to the classification of equine herpesviruses. Arch. Virol. 1986, 90, 273-288.

Darlington $R$, Moss $L \cdot$ Herpesvirus envelopment. J. Virol. 1968, 2, 48-55.

Darlington $R$, Moss $L$. The envelope of herpesvirus. Progr. Med. Virol. 1969, 11, 16-45.

Fong $C$, Hsiung $G$ Development of an equine herpesvirus in two cell culture systems: light and electron microscopy. Infect. Immunity 1972, 6, 865-876.

Gimeno E, Nosetto E, Martın A, Galosi C, Ando $Y$, Etcheverrigaray $M$. Demonstration of equine herpes virus 1 (EHV-1) in histological sections and tissue cultures by the peroxidaseantiperoxidase technique. J. Vet. Med. 1987, 34, 740-742.

Howard CR, Sundquist B, Allan J, Brown SE, $C h e n S-H$, Morein $B$ : Preparation and properties of immune-stimulating complexes containing hepatitis B virus surface antigen. J. gen. Virol. 1987, 68, 2281-2289. 
Jeleff $W \cdot$ Beitrag zur fetalen Histopathologie des Virusabortes der Stute mit besonderer Berücksichtigung der Differential Diagnose. (Contribution to the fetal histopathology of equine virus abortion, with special attention to the differential diagnosis). Arch. Exp. Vet. Med. 1957, 11, 906-920.

Kyhse-Andersen $J$ : Electroblotting of multıple gels: a simple apparatus without buffer tank for rapid transfer of proteins from polyacrylamide to nitrocellulose. J. Biochem. Biophys. Methods 1984, 10, 203-209.

Laemml $U K$ Cleavage of structural proteins during the assembly of the head of bacteriophage T4. Nature 1970, 227, 680

Morein B, Sundquist B, Höglund S, Dalsgaard K, Osterhaus A: ISCOM. A novel structure for antigenic presentation of membrane proteins from enveloped viruses. Nature 1984, 308, 457-460.

Nil S, Morgan C, Rose H: Electron microscopy of herpes simplex virus. J. Virol. 1968, 2, 517536.

O'Neill F, Issel C, Henk $W$ Electron microscopy of equine respiratory viruses in organ cultures of equine fetal respiratory tract epithelium. Amer. J. Vet. Res. 1984, 45, 1953-1960.

Prickett $M$. The pathology of disease caused by equine herpesvirus 1. Proc. 2nd Int. Conf. Equine Infectious Diseases 1970, p. 24-33.
Turtinen l: Studies on the antigenic and genetic variation between the two subtypes of equine herpesvirus-1. PhD. diss., University of Kentucky, 1983.

Westerfield C, Dimock $W$. The pathology of equine virus abortion. J. Amer. vet. med. Ass. 1946, 109, 101-111.

Wong F, Spearman J, Smolenski M, Loewen P: Equine parvovirus: initial isolation and partial characterization. Can. J. comp. Med. 1985, 49, 50-54.

\section{Sammanfattning \\ Immunohistologiska och elektronmikroskopiska undersökningar påvisar herpesvirus-1 l lever, lunga och mjälte från aborterade föl Immunohistologiska försök, med primärantikrop- par mot höljeproteiner hos herpesvirus-1, påvi- sade virus $\mathrm{i}$ nekrotiska zoner $\mathrm{i}$ levern samt $\mathrm{i}$ cytoplasma hos leverceller både med och utan intranukleära inklusionskroppar. Degenererat bronkioliepitel och retikulärceller i mjältens röda pulpa visade också tydlig infärgnıng. Resulta- ten bekräftades med elektronmikroskopiska stu- dier.}

(Accepted August 5, 1988)

Reprints may be requested from: Lars Jönsson, Laboratory of Pathology, National Veterinary Institute, P. O. Box 7073, S-750 07 Uppsala, Sweden. 